\title{
Use of Modern Information Technologies for Countering Corruption in the Executive Authorities
}

\author{
Olga A. Astafurova, Anna S. Borisova, Eyda V. Golomanchuk, and Tatyana Y. Yagotinsteva
}

\begin{abstract}
The article describes the examples of experience of using information systems in anti-corruption activities of executive agencies in the Republic of Tatarstan, Yamal-Nenets Autonomous area, Volgograd and Tula region of Russian Federation. The points raised in the article are: tactics and methodology of countering corruption within the executive agencies of Russian Federation territorial entities.

Within the framework of further development of anti-corruption system in the executive agencies of Russian Federation territorial entities, it was suggested to create a new and unique information analysis system. It is expected to test this system with the public authorities of Volgograd region. It was considered, that an active interregional cooperation is needed in the field of anti-corruption activities as well as the most progressive practices introduction in anti-corruption activity throughout all territorial entities of the country.
\end{abstract}

Index Terms-Anti-corruption activity, methodology, executive agencies, information analysis system, digital methods in anti-corruption activity.

\section{INTRODUCTION}

The efficient activity and existence of the State, its functioning as a system, as an integral "organism", depends directly on the orderly operation of all State structures, established specifically to exercise powers of government authorities. Corruption at the level of the above-mentioned structures, disturbs their normal performance, that would result in malfunction of the entire State "organism" and impedes the achievement of the State objectives.

Every year, the International non-governmental organization Transparency International rates countries based on corruption degree, using the corruption perception index. Thus, the index indicator equal to zero shows total

Manuscript received May 20, 2019; revised January 11, 2020. The reported study was funded by RFBR according to the research project № 18-29-16119 "Formation of the anti-corruption environment in the state and municipal authorities through the introduction of the information and analytical system "Methods and tactics of countering corruption for state and municipal employees"".

Olga A. Astafurova and Anna S. Borisova are with the Information Systems and Mathematical Modelling Department, Volgograd Institute of Management - the Branch of Russian Presidential Academy of National Economy and Public Administration RANEPA, Volgograd, Russia (e-mail: astoa@vlgr.ranepa.ru, Borisova-AS@mail.ru).

Eyda V. Golomanchuk is with the Department of Constitutional and Administrative Right, Volgograd Institute of Management - the Branch of Russian Presidential Academy of National Economy and Public Administration RANEPA, Volgograd, Russia (e-mail: golomanchukav@mail.ru).

Tatyana Y. Yagotinsteva is with the Anti-corruption Department of the Directorate for Public Service and Personnel, the Volgograd Region Governor's Administration, Volgograd, Russia (e-mail: vorobey.25@mail.ru). absence of corruption in a country; the indicator 100 displays the highest level of corruption prevalence in a country. As for 25 August 2018, Russian Federation took the 135 place in this rating with corruption perception index equal to 29 , sharing this position with such countries as Honduras, Laos, Dominican Republic, Kyrgyzstan, Paraguay [1]. The index of corruption degree in Russia has not changed since 2015 [2] and it is a matter of concern. Such a situation means that the anti-corruption measures put into place are ineffective and at the same time, it shows the necessity of their improvement and expansion.

\section{Problem Statement}

Accordingly to the regulations of the art. 1 of the Federal Law dated 25 December 2008 № 273-Ф3 «Concerning anti-corruption activity» [3] anti-corruption activity concerns all levels of state authority, local authorities, civil society institutions, organizations and individuals within their competences to prevent corruption. It also means detection and further elimination of corruption causes (prevention of corruption), detection, prevention, suppression, detection and investigation of corruption-related offences (fight against corruption), minimization and (or) dealing with impact of corruption offences.

Anti-corruption activity, as well as any other goal-oriented activity, includes such integral parts as tactics and methodology, which ultimately determine its efficiency. If we turn to dictionaries, we may find out, that tactics is an integral part of the martial art, which describes theory and practice of combat, and also has several transferred meanings. For example, according to S.I. Ozhegov's glossary tactics is a combination of means and techniques needed to achieve the intended goal [4]. The legal dictionary gives the following definition: tactics is a short-term behavior, a course of action, intended for a relatively short period, based on the current situation [5]. With regard to anti-corruption activity, tactics should be understood as a complex of specific measures used in this activity.

The complex of measures, reflecting anti-corruption activity tactics, should be made sustainable through regional programs and departmental anti-corruption plans, developed under the National anti-corruption plan. The anti-corruption program in Volgograd region for 2018 - 2020 years was approved by the Volgograd region Governor's decree № 622 [6] dated 11 September 2018. In particular, this program will focus on creation and maintenance of conflict commissions, on advanced professional training organization, on legal education of public and municipal officials. Is should also enable anti-corruption expertise of normative legal acts and 
projects, develop anti-corruption mechanisms in personnel policies within executive and local-government bodies etc.

In various dictionaries, methodology is defined as a set of methods for doing something in practice [4], and as specification of a method, its transformation into an instruction and a clear description of how it works [7]. Within the context of the present topic, methodology should be understood by the modalities of anti-corruption activities and measures realization.

Since corruption within the public authorities is considered as the most dangerous one, it makes sense to analyze practically applied anti-corruption measures specifically within the above-mentioned bodies.

One of the basic directions of anti-corruption activities within the executive agencies of Russian Federation territorial entities includes work with data on incomes and expenses, work with data about property and property related obligations (hereinafter referred to as data on income), reported by civil officers. This kind of work involves consultations, information and awareness-raising sessions for public officials regarding the rules of filling the income certificates, the procedure of such data reporting, analysis of data, provided by the officials, with a view to identifying inconsistencies and to establishing grounds for conducting monitoring activities etc [8].

The analysis of data on income implies comparing it with the same data, that had been reported by the public officers in the previous year. In order to reduce the amount of ineffective and non-resultative control measures, a practice has been introduced in the matter of requesting information about the officials' financial status from the competent authorities and organizations of Volgograd region. It helps to make prior assessment of accuracy and completeness of data on income reported by them.

In many constituent entities of the Russian Federation, including the Volgograd Region, the system for the monthly issuance of a newsletter containing information on amendments to the anti-corruption legislation has been well established; judicial practice analytics on holding responsible for corruption offenses; investigation of typical mistakes made when state and municipal employees provide information on income, expenses, property and property obligations.

When conducting an analysis of income information, personnel services are endowed with the following powers:

- send inquiries,

- conduct interviews with employees with their consent,

- receive from the employees with their consent the necessary explanations,

- study the information obtained during the analysis.

However, as the study of practice shows, not all bodies use the granted powers when conducting an analysis, not all send requests. Unfortunately, employees often categorically refuse to give explanations on controversial issues, which often entails bringing to a more stringent form of legal liability.

Note that article 59.1 of Federal Law No. 79-Ф3 for non-compliance by civil servants with restrictions and prohibitions, requirements to prevent or resolve a conflict of interest and non-fulfillment of obligations established in order to combat corruption by Federal Law No. 79-Ф3,
Federal Law No. 273-Ф3 and other federal laws, the following penalties are imposed:

1) remark;

2) reprimand;

3) a warning of incomplete job compliance.

Article 59.2 of Federal Law No. 79-FZ stipulates that a civil servant is subject to dismissal in connection with the loss of confidence in the event of:

1) failure to take measures to prevent and (or) resolve a conflict of interest;

2) failure to provide information on their income, expenses, on property and liabilities of a property nature, as well as on income, expenses, on property and property liabilities of their spouse (spouse) and minor children, or the submission of knowingly false or incomplete information;

3) participation on a paid basis in the activities of the governing body of a commercial organization;

4) entrepreneurial activity;

5) joining the composition of governing bodies, board of trustees or supervisory boards, other bodies of foreign non-profit non-governmental organizations and their structural units operating in the territory of the Russian Federation, unless otherwise provided by an international treaty of the Russian Federation or legislation of the Russian Federation;

6) violation by the employee, his spouse and minor children of the ban on opening and having accounts (deposits), storing cash and valuables in foreign banks located outside the territory of the Russian Federation, owning and (or) using foreign financial instruments.

The use of all the powers granted during the analysis would allow the personnel services, on the one hand, to more carefully analyze the information provided and respond to detected violations in a timely manner, and on the other hand, minimize the number of so-called «zero» checks. It would also lead to the prosecution of truly guilty employees.

Analytical work with data on income is a quite labor-intensive process. In order to facilitate and accelerate this process, the authorities of several regions develop their own methodologies or apply methodologies, created by other organizations for the purposes of data processing using computer technologies and information systems.

\section{ANALYSIS OF INFORMATION TECHNOLOGIES USED IN ANTI-CORRUPTION ACTIVITIES}

\section{A. Inquiry System EGRIP (Unified State Register of Private Entrepreneurs) and EGRUL (Unified State Register of Legal Entities)}

For the purposes of rising the efficiency of anti-corruption measures, Volgograd region executive agencies use the software complex «Inquiry system EGRIP (Unified State Register of Private Entrepreneurs) and EGRUL (Unified State Register of Legal entities) ». For example, by means of electronic access to the above-mentioned resource, it is possible to check whether public officers and citizens, seeking for employment in the civil service, are engaged in business activity as private entrepreneurs, or participate in 
the administration of any commercial and non-commercial organization, as well as to reveal facts of conflict of interests.

\section{B. SPARK-R}

The anti-corruption program in Volgograd region for 2018 -2020 , provides access to the information product designed by the international information group "Interfax" - the SPARK-R system, for the officials of the Corruption and other offences prevention unit of the Civil service and Personnel directorate of Volgograd region Governor's administration. It has been done in the frame of efficiency-raising activities of Volgograd region authorities in the sphere of countering corruption. This system has been designed to check information accuracy and contractual partners reliability by organizations; it is supposed to use SPARK-R in the Volgograd region Governor's administration for detecting signs of affiliation, in other words the relationship between public officials and persons, holding public positions in Volgograd region and different companies and other physical persons. For this purpose, the system reflects not only the current state of the relationships, but their existence in the past, that will make possible to establish facts of possible violations with greater precision.

\section{Software Application for Verification of Data on Income, Reported by Public Officials}

The government of Tula region has developed an autonomous software application for verification of data on income, reported by public officials. The use of this software application supposes public officials' personal data entry in the database as well as information placement about their property status. To start the process of income data analysis and verification it is necessary to scan a QR-code, which is placed on the lower-left of the paper copy of the certificate, submitted by the official. This form should be filled in a specially designed program "Certificates-BK". In the process of scanning, the software application automatically reads data about the person, contained in the certificate and compares it with personal data stored in the electronic database. In the event of discrepancy of such data, the software application delivers the result of verification «Verification failed» and specifies data, which does not match while compared. This situation arises, for example, in case of personal identification document replacement, when its number is changed, or a women changes her surname after marriage.

After public official's data verification, the software application proceeds to the next stage in which it compares personal data on income for the current and prior reporting periods, also shows discrepancies in the data, and what is more, it reflects their justification.

\section{Unified Information System for Human Resources}

The Unified information system for human resources was developed in the Republic of Tatarstan, which is aimed to provide quick access to the information about staff composition of any executive body, to undertake staff review, to standardize human resource procedures and to transfer and update data online. The number of functionalities of the system include: maintenance of personnel management system, as well as staff members' personal data and personal files processing, keeping of the executive body staff registry, maintenance of personnel reserve data, reports generation, including statistic ones, and also anti-corruption functions.

The objective of anti-corruption operation of the Unified information system for human resources is to fill in income certificates in electronic form; to register public officials' property status and to keep records of its history; to enter data about any other remunerated activity, carried by the officials; to enter data and results of any in-service reviews held against public officials; to enter data about meetings of the commissions on compliance with the requirements of the officials' conduct and about management of conflicts of interests; to enter data about reasons for such meetings and the following decisions.

The Integrity of this information systems helps to monitor personal data of any public official and to update automatically personal data for filling out income certificates, as well as to take into consideration any other remunerated activity, conducted by the officials in the process of verification of their data on income.

\section{E. Unified Information System of Volgograd Region}

At present, the Civil service and Personnel directorate of Volgograd region Governor's administration is developing a unified information system, which will include both personnel management functions and a wide range of procedures in the field of anti-corruption activities. It is supposed that except options, analogical to similar systems, this information system will make possible to forward requests to the appropriate authorities by means of electronic workflow, as well as to analyze automatically data on income, reported by public officials, and to receive information, in response to requests, from designated authorities and organizations.

\section{F. Testing System INDIGO}

From 2016, the Department for specific activities of the Yamal-Nenets Autonomous area, has been successfully implementing the «Plan of legal education in the field of anti-corruption activities», which includes holding of thematic sessions with the participation of public officials, distribution of the relative legal documentation, development of guidance materials on the sessions issues, advisory work, final assessment organization on a regular basis (on a quarterly basis) aimed to assess the officials level of knowledge on the subject matter, further performance analysis and implementation of "work on errors". By means of a systematic approach, this practice helps to enhance effectiveness of the advisory work, to raise the public officials' competence level in the field of anti-corruption activity and to integrate separate methods of corruption offences prevention into a unique practice. The «Testing system INDIGO» is applied in order to automate the process of public officials testing in the Department for specific activities of the Yamal-Nenets Autonomous area. This electronic system helps to organize tests, contests and academic contests, to conduct surveys, to assess the officials' qualification level.

\section{G. Unified System of Anti-corruption Work Monitoring}

Among the number of innovative methodologies of 
anti-corruption activities, a special software for the automated information system called "Unified system of anti-corruption work monitoring" is being used in the executive agencies of Russian Federation territorial entities. It helps to automate the processes of reporting and statistic information production and storage in the field of anti-corruption activity.

\section{H. The Proposed Information Analysis System «Methodology and Tactics of Anti-corruption Activity»}

The descriptive analysis of information technologies in the area of anti-corruption activity affirms the need for continued work on support and development of information resources in this area.

The Volgograd region information system in the sphere of anti-corruption activity is not efficient on a number of grounds. Firstly, it is not systematic and focuses exclusively on systematizing the process of providing details about incomes, expenditures, property and property obligations by the public officials. Secondly, it is not a universal system and it is not used at the level of the municipal service. At the level of federal service (both civil and other kind of service) there are some personnel related software applications, but they are not used within all authorities and organizations. Thirdly, none of the existing platforms provides access to tutorial materials and further control of the level of learning.

The most pressing challenge therefore is to create a new information product, which would reflect an integrated approach to the questions of personnel training and retraining and would help to form an anti-corruption environment of state and municipal bodies.

As part of research carried by the authors of the article, an information analysis system is being created, designed to contain data in the following areas: regulatory support of anti-corruption activity at the level of state and municipal service, practicalities of countering corruption, guidelines and methodical recommendations for anti-corruption practices, video lectures, video tutorials and workshops. In the future, it is planned to test the designed system in the public authorities of Volgograd region. The software program to be developed, includes a database, created on the basis of a wide scope of theoretical and practical sources, a training and testing unit, which comprises both training of public officials and metrical methods of knowledge and competence assessment, as well as a unit of additional materials, which will contain regulatory and consultative data [9]. The programs are coded in C\# language, within the development environment Visual Studio.

The information analysis system will give the possibility to carry out monitoring, analysis, planning and forecasting of key indicators of anti-corruption processes with further visualization of results and report generation. The proposed development is unique both in structure of the information analysis system and in data contained, and it will be possible to replicate it.

The information analysis systems operation starts with user authorization window. It is necessary to differentiate user roles for trainees and supervisors (HR representatives).

The designed interface of a user, undergoing training in the information analysis system, includes the following tabs:
1) information tab (contains information about the training complex),

2) rules and regulations (contains all the necessary legal acts to review),

3) tutorial unit (infographics, video-lectures and video-tutorials),

4) test block (test of proficiency in learned material, psychological tests),

5) control block (consists of the subsystem "my results", which shows the results of tests passed and information messages from the reviewing officers; «user account management», which helps to change the user's password).

Except the user's interface, the system contains the reviewing officers' interface. This interface includes the following tabs:

1) Commands - make possible to add or delete any user of the system, to assign a login, a password, to determine his/her position and internal affiliation, to mention the lengths of service, and public service period. All data about new users are stored in the database. The database is established in the Database management system Microsoft Access.

2) Data viewing - the analytical component, which helps to track results of all users testing.

3) Mailing list - makes possible to add users into the mailing list, appoint day and time for the next testing. Such message will appear in the tab "Organizer tab page" under the user mode of the program. The whole correspondence will be stored in the database.

The anti-corruption measures proposed by the authors are based on many years of experience and can help ensure the effectiveness of the various departments of state and municipal authorities on the implementation of anti-corruption measures. The information and analytical system being developed, in addition to the functions already listed, is designed to facilitate the work of personnel services in maintaining documentation regarding the prevention of corruption offenses. In particular, it is planned to automate the work of:

- maintaining a register of training on the prevention and combating corruption,

- keeping a journal of checking the level of knowledge of employees in the field of anti-corruption in the form of testing,

- generating a report on the implementation of training activities,

- generation of a report on checking the level of knowledge of the anti-corruption legislation and public service,

- formation of a report on the identification of the psychological prerequisites of corruption among public servants,

- generating a report of corruption risks in personnel work and making managerial decisions. Anti-corruption procedures for the employment of relatives.

In addition, it is planned to add methodological recommendations on conducting trainings aimed at anti-corruption legal education and studying anti-corruption mechanisms that form a negative attitude of employees 
towards any facts of corruption.

\section{CONCLUSION}

The system of fight against corruption includes many different elements, including measures and means of prevention of corruption and struggle with it.

The article presents the results of the analysis of the use of information technologies in the anti-corruption activities of the Executive authorities of a number of subjects of the Russian Federation. It is concluded that none of the currently operating platforms provides access to training materials together with the ability to control their assimilation. The work of the existing information systems is mainly aimed at systematization of the process of providing information about property and property obligations, as well as the income and expenses of civil servants.

The information and analytical system proposed by the authors will allow to develop a preventive direction, provide an objective assessment of the anti-corruption environment and forecast its development, as well as facilitate the work of human resources services to document the learning processes, monitor the quality of training.

Other territorial units of Russian Federation possess an interesting in the area of countering corruption. In our opinion, an active interregional cooperation is needed to create an efficient anti-corruption system. The most progressive practices should be implemented over all the territory of constituent entities of the country.

\section{CONFLICT OF INTEREST}

The authors declare no conflict of interest.

\section{AUTHOR CONTRIBUTIONS}

Tatyana Y. Yagotinsteva carried out data collection; Eyda V. Golomanchuk analyzed the data; Olga A. Astafurova developed the architecture of the information and analytical system; Anna S. Borisova developed a set of visual materials for the information and analytical system; Olga A. Astafurova and Anna S. Borisova wrote the paper; all authors had approved the final version.

\section{REFERENCES}

[1] Rating of the world countries subject to corruption perception index $\begin{array}{lll}\text { [Digital resource]. } & \text { [Online]. }\end{array}$ https://gtmarket.ru/ratings/corruption-perceptions-index/info

[2] RBC: Russian and Honduras shared the $135^{\text {th }}$ place of the Transparency corruption index perception [Digital resource]. [Online]. Available: //www.rbc.ru/society/21/02/2018/5a8d679c9a79472b4c8bbb7d.

[3] Federal law dated 25.12.2008 № 273-Ф3, “About anti-corruption management," Rossiyskaya Gazeta, no. 266, 2008.

[4] S. I. Ozhegov and N. U. Shvedova, Russian Language Glossary, 2010.

[5] Law dictionary [Digital resource]. [Online]. Available: http://vslovare.info/slovo/juridicheskiij-slovar/taktika/349344

[6] Volgograd region Governor's decree dated 11 September 2018 2018, "Concerning approval of the anti-corruption program in Volgograd region for 2018-2020 year," no. 622 .

[7] B. A. Rayzberg et al., Modern Economic Dictionary, 1999, p. 479

[8] E. V. Golomanchuk et al., "Some problems of providing information about income, expenditure, property and property obligations by the state civil officers and the ways of their settlement," Business Education Right, 2019, pp. 249-254.
[9] O. A. Astafurova et al., "A conceptual model of a practice-oriented information-analytical system for combating corruption," Business Education Right, 2019, pp. 238-243.

Copyright $\odot 2020$ by the authors. This is an open access article distributed under the Creative Commons Attribution License which permits unrestricted use, distribution, and reproduction in any medium, provided the original work is properly cited (CC BY 4.0).

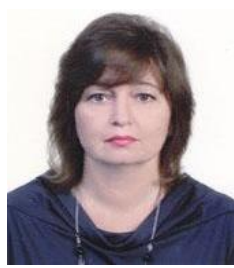

Olga A. Astafurova was born in Orel city (Russia) on 29 August 1967. In 1989 she graduated from Volgograd State University, majoring mathematics. In 2007 she gained an academic degree of $\mathrm{PhD}$ in Engineering Science (Moscow, Russia) and in 2010 was awarded an associate professor's degree.

From 1989 to 1994 she was working as a software engineer of an experimental design office "Robots" In 1994-1996 she worked as a teaching assistant at the Department of Applied Mathematics and computation engineering of Volgograd construction-engineering institute. Since 1996 she has been working at Volgograd Institute of Management - the branch of Russian Presidential Academy of National Economy and Public Administration RANEPA holding positions of the assistant lecturer, senior teacher and senior lecturer. From 2009 to the present day she is the Head of the Information systems and mathematical modelling department of Volgograd Institute of Management the branch of RANEPA. Research interests include: mathematical modelling, information technologies, state economic regulation, electrodynamics, UHF and EHF technology.

Dr. Astafurova was awarded the Certificate of Honor issued by Russian Federation Ministry of Education and Science for her major contribution to the sphere of education and for years of dedicated labour.

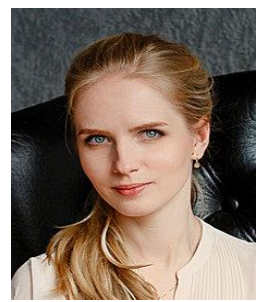

Anna S. Borisova was born in Volgograd (Russia) on 02 November 1989. In 2010 she was conferred Bachelor's degree in business-informatics in Volgograd State University. In 2012 she acquired Master's degree in applied mathematics in Volgograd State University. In 2014 she acquired the Degree of Candidate in Economics (Volgograd, Russia).

From 2015 to 2017 she was working at Volgograd State University as a Senior research fellow and Senior educator. From 2017 she has been working at Volgograd Institute of Management - the branch of RANEPA in the capacity of senior lecturer. Academic research field: information technologies, information society, electronic government, mathematical modeling of socio-economic processes.

Dr. Borisova is the Prize laureate of RF President for support of talented young people, the Prize laureate of Volgograd region in science and technology.

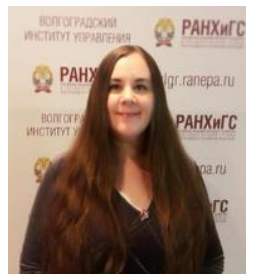

Eyda V. Golomanchuk was born in Russia on 07 March 1982 г., she is a Candidate of legal sciences, senior lecturer of the department of constitutional and administrative right in the Volgograd branch of the Federal State Budgetary Educational Institution of Higher Education (FGBOU VO RANEPA) "Russian Presidential Academy of National Economy and Public Service" In 2004 she graduated with honors from the law faculty of FGOU VPO "Volgograd Academy of civil service", in 2016 she accomplished with honors Master's degree program majoring in "Social psychology" in VB of RANEPA. In 2006, she defended her candidate thesis for the degree of Candidate of legal sciences majoring in constitutional right; municipal right - 12.00.02.

She has been working in Volgograd Branch of RANEPA from 2010 in the capacity of Senior lecturer of the department of constitutional and administrative right. Before doing that, from 1999 she was in public service at Federal Service of State Registration, Land Register and Mapping (Rosreestr) to Volgograd region. She pursues cooperation with the legislative, executive and judicial authorities of Volgograd region. She is member of Commissions for control over compliance with requirements of official conduct, formed in Volgograd regional Duma, in Volgograd region Governor's administration, in the Federal Penitentiary service of Volgograd region. She delivers lectures and conducts tutorial workshops in governmental authorities of different levels, holds public training events for state and municipal officials in the field of anti-corruption management. Research interests include: constitutional social and economic rights of a person and a citizen; issues of administrative responsibility; administrative 
process; legal regulation of public service; legal aspects of anti-corruption management.

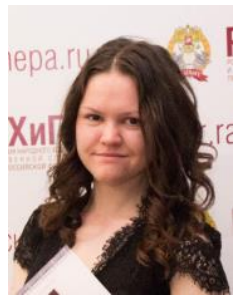

Tatyana Y. Yagotinsteva was born in Russia on 25 January 1994.

In 2016, she accomplished with honors the Bachelor's degree program of VB of FGBOU VPO

RANEPA in the field of study "Jurisprudence", in

2018 she accomplished with honors the Master's

degree program of Volgograd Institute of

Management majoring in "Law enforcement in criminal proceedings". In 2019, she accomplished with honors the Master's degree program of Volgograd Institute of Management - the branch of RANEPA in "Civil, family and international private law".

She has been working at the Volgograd region Governor's administration in the capacity of a Chief specialist of the Anti-corruption department of the Directorate for public service and personnel. Research interests include: legal regulation of public service, anti-corruption management, criminal law, protection of human and civil rights. 